Sains Malaysiana 49(8)(2020): 2023-2034

http://dx.doi.org/10.17576/jsm-2020-4908-25

\title{
Ukuran Kebersandaran bagi Pulangan Lima-Minit Berbanding Pulangan Harian menggunakan Kopula Statik dan Dinamik
}

(Dependence Measure of Five-Minutes Returns Compared to Daily Returns using Static and Dynamic Copulas)

\author{
NURUl HANis AMINUdDIN JAFRY*, RUZANNA AB RAZAK \& NORISZURA ISMAIL
}

\begin{abstract}
ABSTRAK
Kajian tentang kebersandaran antara pasaran saham adalah penting kerana kemampuannya memberi petunjuk dalam proses membuat-keputusan bagi mengatur strategi pelaburan. Kebanyakan kajian lepas mengukur kebersandaran antara pasaran saham menggunakan kopula statik. Walau bagaimanapun, sejak beberapa tahun kebelakangan ini, kopula dinamik telah digunakan sebagai kaedah alternatif bagi mengukur kebersandaran kerana keupayaannya untuk memodelkan kebersandaran masa-berubah antara pasaran saham. Kebanyakan kajian berkaitan kopula lebih tertumpu kepada korelasi data bivariat bagi pulangan harian atau mingguan atau bulanan untuk menjelaskan pergerakan bersama antara pasaran kewangan dan sebagai petunjuk kewangan bagi aspek pengurusan portfolio. Namun begitu, maklumat daripada data berfrekuensi rendah tidak lagi mampu untuk menampung aktiviti perdagangan berskala besar. Sebaliknya, data berfrekuensi tinggi mengandungi maklumat yang lebih banyak mengenai pasaran saham di samping berupaya mencerminkan kemeruapan pasaran saham dengan lebih tepat. Oleh itu, kajian ini bertujuan untuk membandingkan kebersandaran antara pulangan lima-minit (atau data frekuensi tinggi) dengan pulangan harian (atau data frekuensi rendah) bagi menentukan sama ada data-data ini mempunyai struktur kebersandaran yang sama atau berbeza. Kedua-dua model kopula statik dan dinamik diguna untuk memodelkan kebersandaran masaberubah dalam data bivariat. Sebagai contoh berangka, data siri pulangan bivariat bagi pasaran Islam (FBMHS) dan konvensional (KLCI) di Malaysia diguna untuk memodelkan kebersandaran data harian dan kebersandaran data lima-minit. Keputusan kajian ini menunjukkan bahawa struktur kebersandaran antara pulangan harian dan logaritma kemeruapan terealis 5-minit adalah berbeza dan kepelbagaian portfolio bagi pasangan KLCI-FBMHS adalah tidak digalakkan. Akhir sekali, siri 5-minit dan model kopula SJC dinamik masing-masing dipilih sebagai set data dan model kebersandaran terbaik.
\end{abstract}

Kata kunci: FBMHS; KLCI; kopula dinamik; pulangan harian; pulangan lima-minit

\section{ABSTRACT}

Studies on dependence between stock markets are crucial because of their indications on the process of decisionmaking in investment strategies. Many previous studies measure the dependence between stock markets using static copula. However, in recent years, dynamic copula has been used as an alternative for measuring dependence due to its capability of capturing time-varying dependence between stock markets. Many copula studies have been focusing on examining the correlation of the bivariate data of daily, or weekly, or monthly returns to explain the co-movement between financial markets and for possible financial directions on portfolio management. However, information of low-frequency data is unable to accommodate large-scale trading activities. On the other hand, high frequency data contains more information about the stock market and has the ability to reflect stock market volatility more accurately. Therefore, this study aims to compare the dependence of the five-minutes returns (or high-frequency data) with the daily returns (or low-frequency data) to determine whether these data have similar or different dependence structures. Both static and dynamic copula models are utilized to capture the existence of time-varying dependence of the bivariate data. For numerical examples, the bivariate returns series of the Islamic (FBMHS) and conventional (KLCI) stock markets in Malaysia are utilized to model the dependence of the daily data and the dependence of the five-minute data. Findings of this paper shows that the structure of dependency between daily returns and 5-minute logarithmic realized variance are different, and portfolio diversification between KLCI-FBMHS pair is not advisable. Finally, the 5-minute series and dynamic SJC copula model are chosen as the best data set and the best dependency model, respectively.

Keywords: Daily returns; dynamic copula; FBMHS; five-minutes returns; KLCI 


\section{PENGenAlan}

Sejak kebelakangan ini, kajian berkisar analisis kebersandaran semakin mendapat perhatian kerana keupayaannya untuk membantu para pelabur dan pengamal industri dalam membuat keputusan dari segi strategi pelaburan dan kepelbagaian portfolio. Berdasarkan kajian lepas, terdapat beberapa kaedah yang boleh digunakan untuk mengukur kebersandaran seperti kaedah korelasi linear Pearson, analisis kointegrasi dan analisis multivariat. Kaedah korelasi Pearson sering digunakan untuk mengukur kebersandaran antara dua pemboleh ubah yang berbeza. Namun, kaedah Pearson mengandaikan set data bertaburan normal dan mengabaikan ciri-ciri taburan leptokurtik yang biasanya wujud dalam data pasaran saham (Aminuddin et al. 2018a; Embrechts et al. 2002; McNeil et al. 2005). Analisis kointegrasi pula sering digunakan untuk mengukur hubungan satu-hala atau dua-hala antara pasaran kewangan bagi tempoh jangka-pendek dan jangka-panjang. Namun, kaedah ini adalah kurang teguh dan mempunyai beberapa kekangan, seperti mengandaikan bahawa taburan mempunyai pola simetri dan gagal untuk menggambarkan ciri-ciri kebergantungan ekor melampau (Liew \& Wu 2013). Analisis multivariat pula tidak sesuai digunakan untuk menganalisis kebersandaran bagi data yang mempunyai pergerakan bersimetri dan efek kontagion (Hussain \& Li 2018).

Kopula merupakan suatu kaedah alternatif untuk mengukur kebersandaran antara pasaran kewangan. Para penyelidik (Cubillos-Rocha et al. 2019; Mokni \& Youssef 2019; Xiao 2020) menggunakan kaedah kopula kerana sifatnya yang fleksibel dan memudahkan proses pemodelan kebersandaran. Dua kelebihan utama model kopula adalah; transformasi pemboleh ubah rawak yang monoton tidak menyebabkan perubahan pada model kopula dan sifat ini penting kerana pemboleh ubah kewangan sering memerlukan transformasi; kopula membenarkan fungsi taburan multivariat diurai kepada fungsi taburan marginal dan fungsi kebersandaran.

Terdapat beberapa kajian lepas yang menggunakan kaedah kopula statik untuk mengukur kebersandaran antara pasaran kewangan (Ab Razak et al. 2016; Aminuddin et al. 2018b; Messaoud \& Aloui 2015; Salma 2015; Shamiri et al. 2011). Mutakhir ini, beberapa penyelidik mula beralih kepada kopula dinamik untuk mengukur kebersandaran yang bergantung kepada masa, yang juga dikenali sebagai kebersandaran masa-berubah. Kopula masa-berubah atau kopula dinamik merupakan suatu pendekatan yang membenarkan variasi dalam struktur kebersandaran dan mengandaikan parameter kebersandaran berubah secara linear (Boubaker \& Sghaier 2016). Kebersandaran dinamik lebih sesuai digunakan sebagai ukuran kebersandaran berbanding versi statik kerana berlakunya bencana kewangan dan putaran perniagaan yang sering mengalami perubahan (Hammoudeh et al. 2014).
Terdapat beberapa kajian mengenai struktur kebersandaran antara pasaran kewangan antarabangsa yang menggunakan kaedah kopula dinamik, antaranya adalah kajian Aussenegg dan Cech (2008) yang menyelidik pergerakan-bersama antara Eurostoxx Index dengan Dow Jones Industrial Index menggunakan kopula Gaussan dinamik dan kopula student-t dinamik, kajian Kara dan Kemaloglu (2016) yang mendapati bahawa pasangan USD-EUR mempunyai suaian terbaik melalui kopula $t D C C$ bagi kopula dinamik dan kopula Gaussan bagi kopula statik, dan kajian Hussain dan Li (2018) yang mengkaji beberapa pasaran saham di China dan mendapati bahawa pasaran saham di negara tersebut mempunyai kebersandaran yang rendah dengan beberapa pasaran di negara maju (Amerika Syarikat, Kanada, United Kingdom, Jerman, Jepun dan Australia).

Kebanyakan kajian yang menggunakan kaedah kopula bagi mengukur pergerakan-bersama dalam bidang kewangan lebih memilih data pulangan harian sebagai sampel kajian. Sebagai contoh, Necula (2010) mendapati bahawa model kopula student- $t$ dan kopula GumbelClayton masing-masing merupakan model kebersandaran yang paling sesuai untuk menggambarkan hubungan pulangan harian BUX-PX50 dan pulangan harian DAXSP500. Kajian yang hampir serupa juga dilakukan oleh Ab Razak dan Ismail (2014), yang mendapati bahawa kopula student- $t$ memberikan suaian terbaik untuk menerangkan kebersandaran antara pulangan indeks KLCI dengan pulangan indeks EMAS di Malaysia bagi tahun 1998 hingga 2005.

Perkembangan teknologi yang pesat pada masa kini telah mencetuskan era data raya dengan kewujudan lambakan maklumat yang tersedia. Data berfrekuensi tinggi seperti data 12-jam, atau data jam, atau data 30-minit, atau data 5-minit, boleh dikategorikan sebagai data raya. Bagi kajian dalam bidang kewangan, data berfrekuensi tinggi boleh mencerminkan kemeruapan pasaran saham dengan lebih tepat, di samping dapat memberikan maklumat yang lebih banyak mengenai pasaran (Dong et al. 2015). Penganggaran kemeruapan yang dihasilkan seterusnya akan memberi impak kepada ketepatan ramalan bagi portfolio pelaburan (Cheong et al. 2017). Menurut Karmakar dan Paul (2018), risiko perdagangan bagi peserta pasaran aktif seperti pelabur berfrekuensi tinggi atau pelabur harian perlu dinilai menggunakan selang masa yang lebih pendek daripada data harian kerana ufuk pelaburan mereka kebiasaanya kurang dari tempoh sehari. Maklumat data harian pula dikatakan tidak lagi mampu untuk menampung aktiviti perdagangan yang berskala besar (Chin et al. 2016). Namun begitu, kajian yang menggunakan model kopula bersama set data berfrekuensi tinggi dalam bidang kewangan adalah sangat terhad. Kajian mengenai data saham berfrekuensi tinggi (seperti data saat, data minit, dan data jam) bagi indeks pasaran di Malaysia juga kurang dilakukan kerana data yang diperlukan adalah data kemeruapan terealis yang tidak boleh diperoleh 
secara terus melalui data atas-talian bagi kebanyakan negara terutamanya negara-negara sedang membangun. Data kemeruapan terealis atas-talian bagi sesetengah negara maju pula merupakan data yang agak lama. Hal ini berbeza dengan data berfrekuensi rendah (seperti data harian, data mingguan, dan data bulanan) dengan proses pemodelannya hanya memerlukan data harga penutup yang boleh diperoleh secara terus melalui data atas-talian.

Dari segi kajian mengenai pasaran saham di Malaysia, terdapat beberapa kajian yang dilakukan mengenai kebersandaran antara pasaran saham Malaysia dengan pasaran saham di negara lain. Sebagai contoh, kajian Shamiri et al. (2011) menyelidik struktur kebersandaran antara indeks Malaysia (KLCI) dengan beberapa indeks di negara lain (STI dan S\&P500), kajian Ab Razak dan Ismail (2014) melihat kebersandaran antara beberapa pasaran saham di Malaysia dan mendapati bahawa pasangan KLCI-EMAS mempunyai kebersandaran yang kuat pada kedua-dua ekor atas dan bawah, dan kajian Thongkamhong et al. (2017) menggunakan model kopula pertukaran Markov untuk mengukur pergerakanbersama antara beberapa komoditi, saham dan bon di Malaysia. Namun, kebanyakan kajian mengenai pasaran saham di Malaysia mengukur struktur kebersandaran menggunakan data harian dan kopula statik.

Kajian ini bertujuan untuk memodelkan kebersandaran masa-berubah (kopula dinamik) dan kebersandaran statik (kopula statik) menggunakan data lima-minit dan data harian bagi harga pasaran saham Malaysia (KLCI dan FBMHS) untuk tempoh Januari 2014 sehingga Disember 2018. Kelebihan utama menggunakan kopula dinamik (atau kopula masaberubah) berbanding kopula statik adalah, ia membenarkan variasi terhadap masa dalam stuktur kebersandaran. Justeru, penggunaan kopula dinamik dapat mengukur kebersandaran masa-berubah bagi pasangan saham KLCI dan FBMHS. Pemilihan data lima-minit sebagai sampel kajian pula dilakukan kerana data berfrekuensi tinggi (data lima-minit) dijangka boleh menghasilkan model kebersandaran yang lebih tepat ramalannya di samping dapat memberikan maklumat pasaran yang lebih banyak serta memberi manfaat kepada pelbagai golongan pelabur. Perbandingan kebersandaran antara data lima-minit (atau data frekuensi tinggi) dengan data harian (atau data frekuensi rendah) turut dilakukan bagi menentukan sama ada data ini mempunyai struktur kebersandaran yang sama atau berbeza. Berdasarkan pengetahuan penulis, kajian kebersandaran menggunakan kaedah kopula dinamik terhadap data pasaran saham berfrekuensi tinggi bagi indeks Malaysia masih belum diterbitkan. Hal ini berlaku kerana data kemeruapan terealis bagi negara sedang membangun seperti Malaysia tidak boleh diperoleh secara terus dari atas talian dan proses pengiraannya juga agak rumit. Justeru, bagi mengisi kelompongan yang ada, siri pulangan bivariat bagi pasaran Islam (FBMHS) dan konvensional (KLCI) di Malaysia dipilih sebagai sampel kajian bagi memodelkan kebersandaran data harian dan kebersandaran data lima-minit. Kedua-dua indeks dipilih kerana ia merupakan indeks utama bagi pasaran saham di Malaysia, dikategorikan sebagai indeks yang diniagakan dan merupakan indeks yang biasa digunakan dalam kajian prestasi pasaran saham. Kemampuan Malaysia dalam mengungguli kategori indikator kewangan Islam seperti yang dilaporkan oleh Reuters (2017) di dalam Global Economy Report 2017/2018 menjadikan pasaran saham Malaysia sangat sesuai bagi kajian perbandingan antara pasaran saham Islam dan pasaran saham konvensional.

Kajian ini disusun kepada beberapa bahagian bagi memudahkan perbincangan. Bahagian kedua memuatkan huraian mengenai data dan metod. Bahagian ketiga pula mengandungi perincian tentang keputusan dan perbincangan hasil kajian. Bahagian keempat memberikan kesimpulan bagi keseluruhan kajian.

\section{DATA DAN METOD}

\section{DATA}

Kajian ini menggunakan indeks FTSE Bursa Malaysia KLCI (FBMKLCI) dan indeks FTSE Bursa Malaysia Hijrah Shariah (FBMHS) yang mewakili pasaran saham konvensional dan Islam. Tempoh kajian bermula dari Januari 2014 sehingga Disember 2018, dengan jumlah cerapan sebanyak 1224 bagi data harian, serta indeks KLCI dan FBMHS masing-masing memiliki jumlah cerapan 88,124 dan 117,504 bagi data selang 5-minit.

\section{MODEL UNIVARIAT}

Pemodelan kopula membenarkan fungsi taburan bivariat diurai kepada fungsi marginal dan fungsi kebersandaran. Oleh itu, kertas ini selanjutnya membincangkan mengenai pemodelan marginal, dan diikuti dengan pemodelan kopula.

Data harga harian ditransformasi kepada data pulangan harian menggunakan persamaan $R_{t}=\ln \left(P_{t}\right)-\ln \left(P_{t-1}\right)$ untuk menangani isu kepegunan pada data asal. Siri masa yang pegun ditentukan melalui ujian Augmented Dickey-Fuller (ADF).

Bagi data lima-minit pula, data asal yang diekstrak daripada terminal Bloomberg ditransformasi kepada logaritma kemeruapan terealis $(\log R V)$ melalui langkah-langkah berikut. Pertama, data harga lima-minit ditransformasi kepada data pulangan satu-hari melalui persamaan $R_{t}=\ln \left(P_{\mathrm{t}}\right)-\ln \left(P_{\mathrm{t}-1}\right)$, dengan $i=2,3,4,5 \ldots$ $m$, dan $m$ adalah jumlah data lima-minit bagi tempoh satu hari. Kedua, data pulangan satu-hari ditransformasi kepada data kemeruapan terialis harian melalui persamaan $R V_{t}^{(d)}=\sqrt{\sum_{i=2}^{m}\left|R_{t, i}\right|^{2}}$, dengan $t=1,2,3, \ldots . . n$, dan $n$ ialah jumlah hari. Akhir sekali, data kemeruapan terialis ditransformasi kepada bentuk logaritma iaitu $\log R V_{t}^{(d)}$. Kajian Dong et al. (2015) mendapati bahawa data log RV menunjukkan kesan yang lebih baik daripada data RV. Selain itu, plot pulangan harian bagi kajian ini dilihat lebih mirip kepada plot log RV berbanding plot RV (Plot-plot yang berkaitan tidak ditunjukkan di sini tetapi boleh diperoleh daripada penulis atas permintaan). 
Siri data harian dalam bentuk $R_{t, i}=\ln \left(P_{t, i}\right)-\ln \left(P_{t, i-1}\right)$ dan siri data lima-minit dalam bentuk $\log R V_{t}^{(d)}$ digunakan untuk pemodelan marginal. Kajian ini menggunakan model ARMA-GARCH bagi taburan ralat normal dan tidak normal untuk menyuai model marginal. Taburan ralat tidak normal turut dipertimbangkan untuk mengambil kira ciri-ciri taburan leptokurtik yang sering wujud dalam data pasaran saham. Komponen ARMA mewakili min bersyarat, manakala komponen GARCH mewakili varians bersyarat.

Model $\operatorname{ARMA}(p, q)-\operatorname{GARCH}(P, Q)$ dengan taburan normal didefinisikan sebagai:

$$
Y_{t}=\alpha_{0}+\sum_{i=1}^{p} \phi_{i} Y_{t-i}+\sum_{j=1}^{q} \theta_{j} \varepsilon_{t-j}+\varepsilon_{t}
$$

dengan $\varepsilon_{t}=z_{t} \sigma_{t}, \quad$ dan $\quad \sigma_{t}^{2}=\omega+\sum_{i=1}^{Q} \alpha_{i} \varepsilon_{t-i}^{2}+\sum_{i=1}^{P} \beta_{j} \sigma_{t-j}^{2} . Y_{t}$ merupakan indeks pulangan saham pada hari ke- $t, \varepsilon_{t}$ mewakili reja terpiawai yang diandai bertaburan normal dengan min 0 dan sisihan piawai $1, \varphi_{i}$ dan $\theta_{j}$ masingmasing adalah parameter autoregresif (AR) dan pekali purata bergerak (MA), $\sigma_{t}^{2}$ merupakan varians bersyarat pada masa t, $\alpha_{i} \varepsilon_{t-i}^{2}$ mewakili komponen ARCH dengan lat $Q$, dan $\beta_{j} \sigma_{t-j}^{2}$ adalah komponen GARCH dengan lat $P$. Kesemua parameter mestilah positif dan $\alpha_{i}+\beta_{j}<1$. Selain taburan Gaussan, taburan Gaussan terpencong, taburan student- $t$, dan taburan Student- $t$ terpencong turut dipertimbangkan bagi pemodelan marginal.

Pemilihan model marginal terbaik dilakukan melalui langkah-langkah berikut. Pertama, kesignifikan anggaran parameter diteliti. Parameter $\beta_{1}$ yang merupakan komponen varians bersyarat bagi model GARCH perlulah signifikan (Ugurlu et al. 2014). Kedua, ujian diagnostik terhadap siri masa iaitu ujian LjungBox Statistik Q dan ujian pengganda Langrage (LM) dilakukan untuk memastikan tiada masalah autokorelasi dan tiada kesan ARCH pada reja terpiawai. Seandainya wujud masalah autokorelasi, maka model marginal dengan lat yang lebih tinggi diperlukan. Akhir sekali, model marginal terbaik dipilih dengan merujuk kepada AIC dan BIC yang paling rendah.

\section{MODEL KEBERSANDARAN}

Reja terpiawai bagi model marginal terbaik ditransformasi kepada sampel pseudo $\left(\mathrm{u}_{\mathrm{i}}, \mathrm{v}_{\mathrm{i}}\right)$ terlebih dahulu melalui persamaan $\left.\left(u_{i}, v_{i}\right) \mid\left(\operatorname{Rank} O_{1 i} / n_{1 i}+1\right)\left(\operatorname{Rank} O_{2 i} / n_{2 i}+1\right)\right\rfloor$, dengan $O_{1 i}$ dan $O_{2 i}$ mewakili cerapan-cerapan bagi model marginal terpilih, manakala $n_{1 i}$ dan $n_{2 i}$ adalah jumlah sampel. Sampel pseudo dengan skala $[0,1]$ diguna untuk memodelkan kebersandaran menggunakan kaedah kopula.

Teorem kopula yang diperkenalkan oleh Abe Sklar pada tahun 1959 menyatakan bahawa fungsi taburan bivariat dihasilkan daripada 'cantuman bersama' antara fungsi-fungsi taburan univariat. Fungsi kumulatif bivariat, $H(x, y)$, didefinisikan sebagai (Nelson 2006):

$$
H(x, y)=C\left[G_{1}(x) G_{2}(y)\right]=C[u, v]
$$

dengan G(.) adalah fungsi kumulatif marginal, C[.] adalah fungsi kopula yang menerangkan kebersandaran, dan $(\mathrm{u}, \mathrm{v})$ adalah pemboleh ubah rawak yang bertaburan seragam piawai. Kajian ini memberi tumpuan kepada enam jenis model kopula iaitu kopula Gaussan, kopula putaran Gumbel, dan kopula SJC, masing-masing dalam versi statik dan dinamik. Model kopula statik dan dinamik dipertimbangkan untuk menentukan sama ada kebersandaran masa-berubah wujud dalam data bivariat.

Model kopula Gaussan merupakan taburan multivariat bersimetri dan digunakan untuk menangani kebersandaran secara keseluruhan. Kopula putaran Gumbel dan kopula SJC pula memiliki kebersandaran tidak bersimetri; kopula putaran Gumbel boleh menangani kebersandaran di bahagian ekor bawah, manakala kopula SJC boleh melihat tingkah laku pasangan saham bagi kedua-dua ekor atas dan bawah. Parameter kebersandaran ekor bawah dan ekor atas yang signifikan masing-masing menunjukkan bahawa pasangan saham mengalami kebersandaran pada waktu krisis dan pada waktu pasaran berkembang pesat ( $\mathrm{Ab}$ Razak \& Ismail 2019).

Kopula Gaussan merupakan keluarga kopula eliptikal, dan didefinisi sebagai:

$$
C(u, v)=\int_{-\infty}^{\phi^{-1}(u) \phi^{-1}(v)} \int_{-\infty}^{\delta x y} \frac{1}{2 \pi \sqrt{1-\delta^{2}}} \exp \left\{-\frac{x^{2}-2 \delta y+y^{2}}{2\left(1-\delta^{2}\right)}\right\} d x d y
$$

atau $C=\Phi_{\delta}\left(\Phi^{-1}(u) \Phi^{-1}(v) \quad\right.$ dengan $-1 \leq \delta \leq 1$ merupakan parameter korelasi linear bagi data bivariat, $\Phi$ mewakili fungsi kumulatif, dan $\Phi^{-1}$ (.) ialah songsangan fungsi kumulatif bagi pemboleh ubah rawak normal terpiawai. Parameter korelasi linear yang berubah merentasi masa $t$ bagi Kopula Gaussan dinamik adalah (Patton 2006):

$$
\delta_{t}=\lambda\left(\omega+\beta \delta_{t-1}+\alpha \frac{1}{10} \sum_{j=1}^{10}\left[\Phi^{-1}\left(u_{t-j}\right) \Phi^{-1}\left(v_{t-j}\right)\right]\right)
$$

dengan koefisien $\lambda$ merupakan transformasi logistik terubah suai untuk memastikan $\delta_{t}$ sentiasa berada dalam julat $(-1,1)$. Persamaan (4) diandaikan mengikut proses $\operatorname{ARMA}(1,0)$, manakala kesan kegigihan dikawal oleh koefisien $\beta \delta_{t-1}$.

Kopula putaran Gumbel merupakan keluarga Archimeden, dan didefinisi sebagai:

$$
C_{P G}(u, v)=u+v-1+C_{G}(1-u, 1-v)
$$

dengan $C_{G}(u, v)=\exp \left(-\left((-\log u)^{\delta}+(-\log v)^{\delta}\right)^{\frac{1}{\delta}}\right)$ adalah kopula Gumbel, dan $\delta \geq 1$ adalah parameter kopula 
(kebersandaran). Kopula Gumbel mempunyai ekor atas bersandar $\left(\lambda_{U}=2-2^{1 / \delta}\right)$ dan ekor bawah tidak bersandar $\left(\lambda_{L}=0\right)$, manakala kopula putaran Gumbel mempunyai ekor atas tidak bersandar $\left(\lambda_{U}=0\right)$ dan ekor bawah bersandar $\left(\lambda_{L}=2-2^{1 / \delta}\right)$. Parameter kebersandaran yang berubah merentasi masa $t$ bagi kopula putaran Gumbel dinamik diwakili oleh Hammoudeh et al. (2014):

$$
\delta_{t}=\omega+\beta \delta_{t-1}+\alpha \frac{1}{q} \sum_{j=1}^{q}\left|u_{t-j}-v_{t-j}\right|
$$

dengan $q$ merupakan jumlah sampel pseudo.

Kopula Simetrik Joe Clayton (SJC) merupakan kopula campuran berbentuk istimewa. Persamaan matematik bagi kopula SJC adalah (Patton 2006):

$$
C_{S J C}(u, v)=0.5\left[C_{J C}(u, v)+C_{J C}(1-u, 1-v)+u+v-1\right]
$$

dengan $\left.C_{J C}(u, v)=1-\left(1-\left\{1-(1-u)^{k}\right]^{-\gamma}+\left[1-(1-v)^{k}\right]^{\gamma}-1\right\}^{\}^{-\frac{1}{\gamma}}}\right)^{\frac{1}{k}}$ adalah kopula Joe-Clayton, $k=\frac{1}{\log _{2}\left(2-\tau^{U}\right)}$, dan $\gamma=-\frac{1}{\log _{2}\left(\tau^{L}\right)}$. Parameter $\tau^{U} \in(0,1)$ dan $\tau^{L} \in(0,1)$ masing-masing mewakili ekor atas dan ekor bawah. Persamaan matematik bagi kedua-dua ekor kopula SJC apabila ia berubah merentasi masa adalah:

$$
\tau^{U}=\tilde{\lambda}\left(\omega^{U}+\beta^{U} \tau_{t-1}+\alpha^{U} \frac{1}{10} \sum_{i=1}^{10}\left|u_{1, t-i}-u_{2, t-i}\right|\right)
$$

$$
\tau^{L}=\tilde{\lambda}\left(\omega^{L}+\beta^{L} \tau_{t-1}+\alpha^{L} \frac{1}{10} \sum_{i=1}^{10}\left|u_{1, t-i}-u_{2, t-i}\right|\right)
$$

dengan koefisien $\tilde{\lambda}$ mewakili transformasi logistik bagi memastikan parameter kebersandaran $\tau^{U}$ dan $\tau^{L}$ berada dalam julat $(0,1)$.

Kaedah Inference Functions for Margins (IFM) merupakan pendekatan yang biasa digunakan untuk menganggar parameter bagi model kopula kerana kebolehannya untuk menangani taburan marginal yang kompleks dan ia adalah lebih cekap berbanding pendekatan Kebolehjadian Maksimum Tepat dan Kebolehjadian Maksimum Canonical (Joe 1997). Kaedah IFM melibatkan dua langkah penganggaran secara berperingkat, didahului dengan pemodelan marginal dan diikuti dengan pemodelan kopula.

\section{KePUtUSAN DAN PERBINCANGAN}

Jadual 1 memberikan rumusan statistik bagi data harga harian dan data harga lima-minit untuk indeks Islam FBMHS dan indeks konvensional KLCI. Kedua-dua data harian dan data lima-minit menunjukkan julat yang lebih besar bagi indeks FBMHS berbanding indeks KLCI, yang menunjukkan wujudnya nilai ekstrim dalam indeks syariah. Nilai CV bagi indeks konvensional adalah lebih tinggi untuk kedua-dua data, yang membuktikan indeks KLCI lebih meruap berbanding indeks FBMHS di sepanjang tempoh kajian. Kes ini mungkin berlaku kerana sokongan kerajaan terhadap perkembangan pasaran kewangan Islam di Malaysia (Ab Razak et al. 2016).

JADUAL 1. Rumusan statistik bagi harga pasaran saham Malaysia

\begin{tabular}{lcccc}
\hline \multirow{2}{*}{ Statistik } & \multicolumn{2}{c}{ Data harian } & \multicolumn{2}{c}{ Data selang 5-minit } \\
\cline { 2 - 4 } & KLCI & FBMHS & KLCI & FBMHS \\
\hline Min & 1750 & 14120 & 1750 & 14118 \\
Median & 1751 & 14080 & 1750 & 14805 \\
SD & 79.17 & 533.67 & 79.13 & 535.72 \\
Maksimum & 1895 & 15350 & 1896 & 15393 \\
Minimum & 1532 & 12500 & 1507 & 3072 \\
Julat & 363 & 2850 & 389 & $3.79 \%$ \\
CV & $4.52 \%$ & $3.78 \%$ & $4.52 \%$ & 0.2089 \\
Ujian ADF & 0.5057 & 0.0678 & 0.5437 & 3072 \\
\hline
\end{tabular}


Ujian ADF untuk data harian memberikan nilai- $p$ yang tidak signifikan, dan membuktikan wujudnya masalah kepegunan. Maka, siri harga harian ditransformasi kepada siri pulangan harian. Ujian ADF juga menunjukkan keputusan yang tidak signifikan pada aras keertian lima peratus bagi data lima-minit. Justeru, siri harga lima-minit ditransformasi kepada siri logaritma kemeruapan terealis.

Jadual 2 menunjukkan rumusan statistik bagi siri pulangan harian dan siri logaritma kemeruapan terealis (data lima-minit). Bagi siri pulangan harian, kedua-dua indeks mempunyai min positif dan menghampiri sifar. Sisihan piawai bagi siri FBMHS adalah lebih tinggi berbanding siri KLCI, yang menunjukkan bahawa indeks Islam lebih meruap berbanding indeks konvensional. Penemuan ini disokong oleh perbezaan yang lebih besar antara nilai minimum dengan nilai maksimum yang wujud dalam indeks FBMHS berbanding indeks KLCI. Siri logaritma kemeruapan terealis pula menunjukkan min bukan sifar dengan magnitud negatif. Sisihan piawai bagi indeks KLCI pula adalah lebih tinggi berbanding indeks FBMHS bagi data lima-minit.

JADUAL 2. Rumusan statistik pulangan harian dan $\log (\mathrm{RV})$ bagi pasaran saham Malaysia

\begin{tabular}{lcccc}
\hline \multirow{2}{*}{ Statistik } & \multicolumn{2}{c}{ Pulangan harian } & \multicolumn{2}{c}{$\log (\mathrm{RV})$} \\
\cline { 2 - 4 } & KLCI & FBMHS & KLCI & FBMHS \\
\hline Min & $7.5 \mathrm{e}-05$ & $6.4 \mathrm{e}-05$ & -5.5920 & -5.4580 \\
Median & $-1.1 \mathrm{e}-03$ & $-4.8 \mathrm{e}-05$ & -5.6360 & -5.5090 \\
Maksimum & $3.2 \mathrm{e}-02$ & $3.6 \mathrm{e}-02$ & -3.7490 & -3.8390 \\
Minimum & $-2.2 \mathrm{e}-02$ & $-3.2 \mathrm{e}-02$ & -6.3720 & -6.2010 \\
SD & 0.0057 & 0.0060 & 0.3488 & 0.3220 \\
Ujian ADF & 0.0100 & 0.0100 & 0.0100 & 0.0100 \\
Pencongan & 0.4650 & 0.3359 & 0.7188 & 0.8482 \\
Kurtosis & 5.6940 & 7.1408 & 3.7966 & 4.3294 \\
Ujian JB & $<2.2 \mathrm{e}-16$ & $<2.2 \mathrm{e}-16$ & $<2.2 \mathrm{e}-16$ & $<2.2 \mathrm{e}-16$ \\
Q(10) & 0.0444 & 0.0097 & $<2.2 \mathrm{e}-16$ & $<2.2 \mathrm{e}-16$ \\
Q ${ }^{2}(10)$ & $<2.2 \mathrm{e}-16$ & $<2.2 \mathrm{e}-16$ & $<2.2 \mathrm{e}-16$ & $<2.2 \mathrm{e}-16$ \\
\hline
\end{tabular}

Nota: Nilai-nilai yang diberikan bagi ujian ADF, ujian JB, $Q(10)$ dan $\mathrm{Q}^{2}(10)$ merupakan nilai-p. $\mathrm{Q}(10)$ dan $\mathrm{Q}^{2}(10)$ adalah statistik ujian Ljung-Box bagi pulangan dan pulangan kuasa dua

Keputusan ujian JB membuktikan bahawa data harian dan data lima-minit bagi indeks KLCI dan indeks FBMHS dikategorikan sebagai taburan tidak normal. Keputusan ini disokong dengan kepencongan yang melebihi sifar bagi data harian dan data lima-minit untuk indeks KLCI dan indeks FBMHS. Kepencongan yang melebihi sifar (kepencongan positif) bermaksud siri indeks lebih kerap mengalami kerugian berbanding keuntungan di sepanjang tempoh kajian. Indeks pasaran saham di Malaysia juga dilihat mempunyai taburan leptokurtik dengan kurtosis yang melebihi tiga. Keputusan ujian ADF menunjukkan bahawa nilai- $p$ bagi data harian dan data lima-minit untuk kedua-dua indeks adalah 0.01. Nilai- $p$ yang signifikan membuktikan bahawa data yang telah ditransformasi bersifat pegun. Ujian Ljung-Box pada lat 10 bagi data harian, data lima-minit, data harian kuasa-dua, dan data lima- minit kuasa-dua adalah signifikan pada aras keertian lima peratus. Keputusan ini membuktikan wujudnya korelasi bersiri dan kemeruapan berkelompok pada data. Kesimpulannya, kesemua set data adalah pegun, bertaburan tidak normal dan memiliki korelasi bersiri dan sesuai untuk dimodelkan melalui model siri masa.

Data pulangan dan data logaritma kemeruapan terealis bagi indeks KLCI dan FBMHS disuai dengan model marginal $\operatorname{ARMA}(p, q)-\operatorname{GARCH}(P, Q)$ bagi empat jenis taburan ralat; normal, normal terpencong, student- $t$ dan student- $t$ terpencong. Pemilihan model marginal terbaik dilakukan dengan merujuk nilai maklumat kriteria terendah.

Jadual 3 memberikan anggaran parameter, ujian diagnostik dan nilai maklumat kriteria bagi model terbaik yang dipilih. Data harian menunjukkan bahawa ARMA(1,2)-GARCH(1,1)-student-t dan ARMA(1,0)- 
GARCH(1,1)-student- $t$ masing-masing adalah model marginal terbaik bagi data indeks KLCI dan FBMHS. Kesemua parameter adalah signifikan pada aras keertian lima peratus, kecuali parameter $\mu$ dan $\omega$. Bagi data lima-minit pula, $\operatorname{ARMA}(2,2)-\operatorname{GARCH}(1,1)$-student- $t$ terpencong merupakan model marginal terbaik bagi kedua-dua indeks. Parameter tambahan yang wujud bagi data lima-minit ialah $\lambda$. Nilai $\lambda$ yang positif dan signifikan membuktikan bahawa reja terpiawai bagi data lima-minit adalah terpencong ke kanan.

JADUAL 3. Model-model ARMA(p,q)-GARCH(P,Q) terpilih

\begin{tabular}{|c|c|c|c|c|}
\hline & \multicolumn{2}{|c|}{ Pulangan harian } & \multicolumn{2}{|c|}{$\log (\mathrm{RV})$} \\
\hline & KLCI & FBMHS & KLCI & FBMHS \\
\hline \multicolumn{5}{|c|}{ Penganggaran parameter } \\
\hline$\mu$ & $\begin{array}{l}-5.0 \mathrm{e}-05 \\
(1.3 \mathrm{e}-04)\end{array}$ & $\begin{array}{l}-5.3 \mathrm{e}-05 \\
(1.4 \mathrm{e}-04)\end{array}$ & $\begin{array}{c}-5.6 \mathrm{e}+00 * * \\
(8.0 \mathrm{e}-02)\end{array}$ & $\begin{array}{c}-5.5 \mathrm{e}+00^{* *} \\
(6.7 \mathrm{e}-02)\end{array}$ \\
\hline$\varphi_{1}$ & $\begin{array}{c}-9.3 \mathrm{e}-01^{* *} \\
(2.8 \mathrm{e}-02)\end{array}$ & $\begin{array}{l}7.1 \mathrm{e}-02 * \\
(2.8 \mathrm{e}-02)\end{array}$ & $\begin{array}{c}1.6 \mathrm{e}+00^{* *} \\
(9.3 \mathrm{e}-03)\end{array}$ & $\begin{array}{c}1.7 \mathrm{e}+00 * * \\
(2.9 \mathrm{e}-03)\end{array}$ \\
\hline$\varphi_{2}$ & & & $\begin{array}{c}-5.6 \mathrm{e}-01 * * \\
(9.1 \mathrm{e}-03)\end{array}$ & $\begin{array}{c}-7.4 \mathrm{e}-01 * * \\
(2.8 \mathrm{e}-03)\end{array}$ \\
\hline$\theta_{1}$ & $\begin{array}{c}9.9 \mathrm{e}-01 * * \\
(1.7 \mathrm{e}-02)\end{array}$ & & $\begin{array}{c}-1.4 \mathrm{e}+00 * * \\
(3.5 \mathrm{e}-04)\end{array}$ & $\begin{array}{c}-1.6 \mathrm{e}+00^{* *} \\
(3.0 \mathrm{e}-05)\end{array}$ \\
\hline$\theta_{2}$ & $\begin{array}{c}5.7 \mathrm{e}-02 * * \\
(1.6 \mathrm{e}-02)\end{array}$ & & $\begin{array}{l}4.1 \mathrm{e}-01 * * \\
(8.0 \mathrm{e}-04)\end{array}$ & $\begin{array}{l}5.9 \mathrm{e}-01 * * \\
(2.5 \mathrm{e}-04)\end{array}$ \\
\hline$\omega$ & $\begin{array}{c}1.0 \mathrm{e}-06 \\
(1.0 \mathrm{e}-06)\end{array}$ & $\begin{array}{c}1.0 \mathrm{e}-06 \\
(1.0 \mathrm{e}-06)\end{array}$ & $\begin{array}{l}1.8 \mathrm{e}-03 * * \\
(5.7 \mathrm{e}-04)\end{array}$ & $\begin{array}{l}1.3 \mathrm{e}-03^{* *} \\
(4.0 \mathrm{e}-04)\end{array}$ \\
\hline$\alpha_{1}$ & $\begin{array}{l}1.1 \mathrm{e}-01 * * \\
(2.6 \mathrm{e}-02)\end{array}$ & $\begin{array}{c}1.0 \mathrm{e}-01 * * \\
(3.1 \mathrm{e}-02)\end{array}$ & $\begin{array}{l}1.9 \mathrm{e}-02 * * \\
(5.8 \mathrm{e}-03)\end{array}$ & $\begin{array}{l}1.7 \mathrm{e}-02 * * \\
(5.0 \mathrm{e}-03)\end{array}$ \\
\hline$\beta_{1}$ & $\begin{array}{c}8.7 \mathrm{e}-01 * * \\
(2.6 \mathrm{e}-02)\end{array}$ & $\begin{array}{c}8.7 \mathrm{e}-01 * * \\
(3.0 \mathrm{e}-02)\end{array}$ & $\begin{array}{c}9.6 \mathrm{e}-01 * * \\
(7.7 \mathrm{e}-03)\end{array}$ & $\begin{array}{c}9.6 \mathrm{e}-01 * * \\
(5.8 \mathrm{e}-03)\end{array}$ \\
\hline$\lambda$ & & & $\begin{array}{c}1.5 \mathrm{e}+00^{* *} \\
(7.9 \mathrm{e}-02)\end{array}$ & $\begin{array}{c}1.4 \mathrm{e}+00^{* *} \\
(6.4 \mathrm{e}-02)\end{array}$ \\
\hline$v$ & $\begin{array}{c}8.0 \mathrm{e}+00 * * \\
(1.7 \mathrm{e}+00)\end{array}$ & $\begin{array}{c}5.0 \mathrm{e}+00 * * \\
(5.9 \mathrm{e}-01)\end{array}$ & $\begin{array}{c}12.9 \mathrm{e}+00^{* *} \\
(3.8 \mathrm{e}+00)\end{array}$ & $\begin{array}{r}8.5 \mathrm{e}+00 * * \\
(1.9 \mathrm{e}+00)\end{array}$ \\
\hline \multicolumn{5}{|c|}{ Ujian Diagnostik } \\
\hline $\mathrm{Q}(10)$ & 0.7378 & 0.3485 & 0.3894 & 0.8446 \\
\hline $\mathrm{Q}(15)$ & 0.9054 & 0.5320 & 0.4072 & 0.8280 \\
\hline $\mathrm{Q}(20)$ & 0.7383 & 0.5791 & 0.5062 & 0.8608 \\
\hline$Q^{2}(10)$ & 0.2439 & 0.5470 & 0.6907 & 0.8556 \\
\hline$Q^{2}(15)$ & 0.0584 & 0.0142 & 0.4834 & 0.7455 \\
\hline$Q^{2}(20)$ & 0.1165 & 0.0522 & 0.3894 & 0.8446 \\
\hline Ujian LM & 0.1518 & 0.6021 & 0.5658 & 0.9090 \\
\hline \multicolumn{5}{|c|}{ Maklumat Kriteria } \\
\hline AIC & -7.7012 & -7.6563 & 0.16005 & 0.03258 \\
\hline BIC & -7.6678 & -7.6313 & 0.20179 & 0.07433 \\
\hline
\end{tabular}

*Nilai adalah signifikan pada aras 5\%,** Nilai adalah signifikan pada aras $1 \%$ 
Nilai- $p$ yang signifikan bagi parameter $\alpha_{1}$ membuktikan wujudnya kelompok kemeruapan bagi kesemua siri. Parameter $\beta_{1}$ bagi kesemua siri adalah positif dan kurang daripada satu, yang menunjukkan bahawa siri data masih memenuhi andaian kepegunan. Kesemua siri dikatakan mempunyai ketegaran kemeruapan yang agak tinggi disebabkan hasil tambah parameter $\alpha_{1}$ dan $\beta_{1}$ yang menghampiri 1 .

Ujian Ljung-Box Q dan ujian LM masing-masing digunakan untuk mengesan kewujudan autokorelasi dan autoregrasif heteroskedastisi bersyarat (ARCH). Keputusan daripada Jadual 3 menunjukkan bahawa nilai- $p$ bagi kesemua set data adalah tidak signifikan bagi kedua-dua ujian, yang mengimplikasikan bahawa model yang dipilih sesuai untuk memodelkan kemeruapan data harian dan data lima-minit.
Jadual 4 dan 5 masing-masing memberikan anggaran parameter kopula dan nilai maklumat kriteria bagi kopula statik dan dinamik yang disuai terhadap data harian dan data lima-minit bagi pasangan FBMHSKLCI. Berdasarkan nilai maklumat kriteria daripada Jadual 4, model kopula Gausan merupakan model statik terbaik bagi data harian. Parameter $\delta$ yang positif dan menghampiri 1 menunjukkan bahawa indeks KLCI dan FBMHS bersandar secara positif dan mempunyai kebersandaran yang kuat. Senario ini adalah seperti yang dijangka kerana sebahagian besar daripada syarikat yang tersenarai dalam indeks KLCI turut tersenarai dalam indeks FBMHS (Ab Razak \& Ismail 2019). Bagi data lima-minit pula, model kopula SJC merupakan model statik terbaik. Nilai $\tau^{U}$ yang lebih besar daripada nilai $\tau^{L}$ menunjukkan wujudnya kebersandaran yang kuat semasa pasaran sedang berkembang.

JADUAL 4. Model kopula statik

\begin{tabular}{lccc}
\hline \multicolumn{1}{c}{ Kopula statik } & & Data harian & Data 5-minit \\
\hline Gaussan & $\delta$ & 0.8832 & 0.8135 \\
& AIC & -1851.71 & -1327.11 \\
& BIC & -1851.70 & -1327.11 \\
\hline Putaran Gumbel & $\delta$ & 3.0165 & 2.2918 \\
& AIC & -1758.38 & -1139.07 \\
& BIC & -1758.37 & -1139.07 \\
\hline SJC & $\tau^{U}$ & 0.7347 & 0.7315 \\
& $\tau^{L}$ & 0.7140 & 0.4552 \\
& AIC & -1811.97 & -1372.43 \\
& BIC & -1811.96 & -1372.42 \\
\hline
\end{tabular}

JADUAL 5. Model kopula dinamik

\begin{tabular}{cccc}
\hline Kopula dinamik & & Data harian & Data 5-minit \\
\hline Gaussan dinamik & $\omega$ & 4.9997 & -1.83067 \\
$\alpha$ & 0.4597 & 0.0559 \\
$\beta$ & -2.9360 & 4.9999 \\
& AIC & -1863.36 & -1331.80 \\
& BIC & -1863.35 & -1331.78 \\
\hline
\end{tabular}




\begin{tabular}{lccc}
\hline Putaran Gumbel dinamik & $\omega$ & 2.5039 & 0.4056 \\
& $\alpha$ & -0.2031 & 0.3321 \\
& $\beta$ & -4.2790 & -0.2320 \\
& AIC & -1777.21 & -1140.93 \\
& BIC & -1777.20 & -1140.92 \\
\hline SJC dinamik & $\omega^{U}$ & 0.7436 & -0.0946 \\
& $\alpha^{U}$ & 0.3465 & -3.1774 \\
& $\beta^{U}$ & 0.3124 & 2.0723 \\
& $\omega^{L}$ & 1.8794 & -0.1549 \\
& $\alpha^{L}$ & -5.5048 & -0.2956 \\
& $\beta^{L}$ & -0.5061 & 0.1336 \\
& AIC & -1821.16 & -1378.27 \\
& BIC & -1821.14 & -1378.25 \\
\hline
\end{tabular}

Keputusan daripada kopula dinamik dalam Jadual 5 menunjukkan bahawa model kopula Gausan dinamik merupakan model terbaik bagi data harian, dan model kopula SJC dinamik merupakan model terbaik bagi data lima-minit, dan keputusan ini adalah tekal dengan kopula versi statik. Bagi data harian, pekali $\beta$ adalah lebih rendah daripada pekali $\alpha$ (kopula Gaussan dinamik), yang menunjukkan bahawa kebanyakan sampel mempunyai gangguan putih. Data lima-minit pula menunjukkan bahawa parameter $\omega_{L}$ adalah lebih kecil daripada $\omega_{U}$, yang mengimplikasikan bahawa kebersandaran antara KLCI dengan FBMHS adalah lebih kuat semasa tempoh normal berbanding tempoh krisis. Keputusan ini juga menunjukkan bahawa kepelbagaian portfolio bagi indeks KLCI dan FBMHS dalam tempoh krisis bukanlah strategi yang berkesan.

Pemilihan kopula terbaik berdasarkan nilai maklumat kriteria tanpa mengambil kira kategori kopula statik atau dinamik menunjukkan bahawa kopula Gaussan dinamik dan kopula SJC dinamik masingmasing adalah kopula terbaik untuk data harian dan data lima-minit. Keputusan kajian ini selari dengan penemuan Hammoudeh et al. (2014) yang menyatakan bahawa kopula dinamik lebih sesuai digunakan berbanding versi statik kerana bencana kewangan dan putaran perniagaan sering mengalami perubahan. Keputusan ini juga menunjukkan wujudnya kebersandaran masa-berubah bagi pasangan KLCI-FBMHS untuk data harian dan data lima-minit.

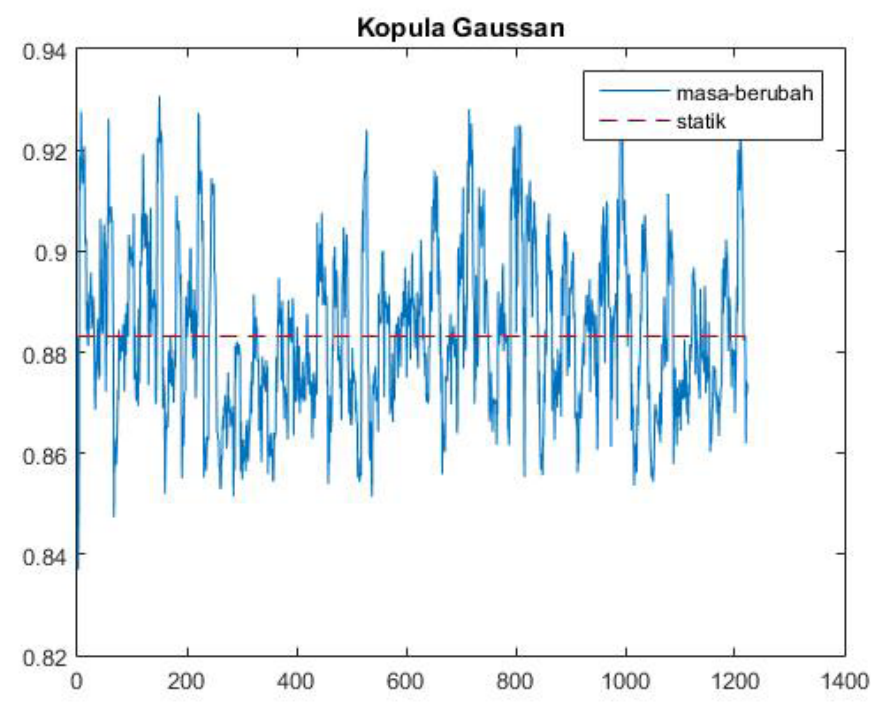

RAJAH 1. Graf kebersandaran kopula terbaik bagi data harian 

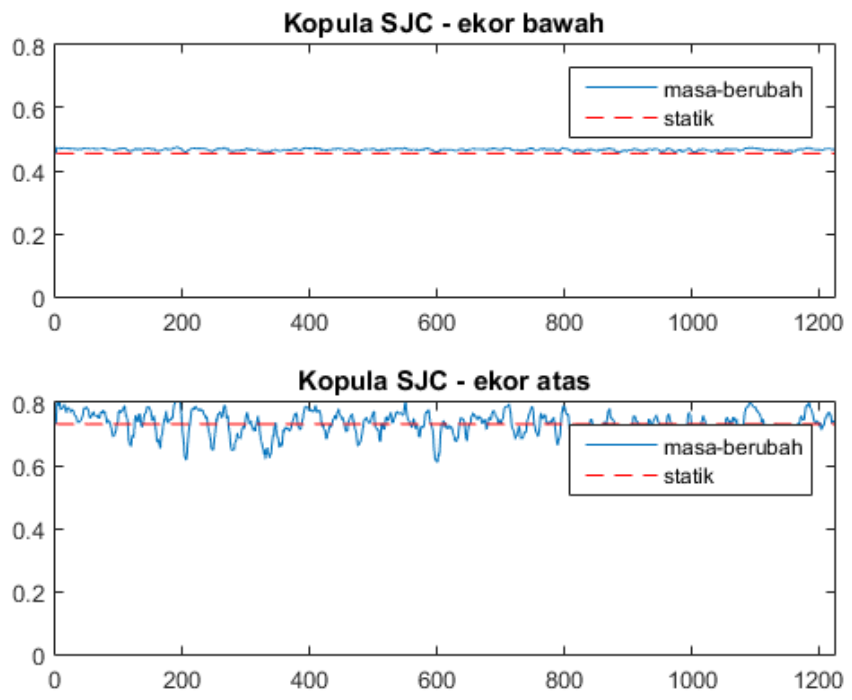

RAJAH 2. Graf kebersandaran kopula terbaik bagi data lima-minit

Rajah 1 dan 2 menggambarkan laluan masa untuk parameter $\delta_{t}$ (Gaussan dinamik), ekor atas $\tau^{a}$ (SJC dinamik), dan ekor bawah $\tau^{b}$ (SJC dinamik), masingmasing bagi kopula terbaik data harian dan data limaminit. Bagi pasangan harian, anggaran parameter kebersandaran berada dalam julat 0.8370 hingga 0.9359. Julat ini menunjukkan bahawa kebersandaran KLCI-FBMHS adalah sangat kuat. Bagi pasangan data lima-minit pula, ekor bawah $\left(\tau^{b}\right)$ dilihat mempunyai kebersandaran yang agak stabil dengan julat 0.4552 hingga 0.4752 , manakala kebersandaran ekor atas $\left(\tau^{a}\right)$ pula dilihat lebih meruap dengan nilai antara 0.5887 hingga 0.8170 .

\section{KESIMPULAN}

Kajian ini telah membandingkan kebersandaran bagi data harian dan data lima-minit. Kedua-dua kopula versi statik dan dinamik diguna untuk melihat sama ada wujudnya kebersandaran masa-berubah dalam data bivariat. Indeks pasaran saham Islam (FBMHS) dan konvensional (KLCI) di Malaysia diguna sebagai contoh berangka untuk memodelkan kebersandaran data harian dan kebersandaran data lima-minit.

Hasil kajian menunjukkan bahawa pasaran saham Islam dan konvensional di Malaysia mempunyai ciri taburan yang sama iaitu terpencong secara positif, berekor tebal dan bertaburan leptokurtik. Hasil penemuan ini selari dengan kajian Ab Razak et al. (2016) yang menyatakan bahawa pasaran saham Islam dan konvensional mempunyai ciri-ciri yang serupa. Walau bagaimanapun, indeks FBMHS dilihat lebih berisiko dan kurang meruap berbanding indeks KLCI.
Bagi pemodelan marginal, perbezaan paling ketara yang dapat dilihat antara data harian dan data lima-minit ialah dari sudut taburan terbaik yang terpilih; taburan student- $t$ merupakan taburan terbaik bagi kedua-dua indeks data harian, manakala taburan terbaik bagi data lima-minit adalah taburan student- $t$ terpencong. Taburan student- $t$ terpencong mempunyai parameter tambahan iaitu $\lambda$. Nilai $\lambda$ yang positif dan signifikan membuktikan bahawa reja terpiawai data lima-minit untuk kedua-dua indeks FBMHS dan KLCI adalah terpencong ke kanan. Keputusan ini adalah dijangka kerana data berfrekuensi tinggi boleh mencerminkan kemeruapan pasaran saham dengan lebih tepat, di samping memberikan maklumat yang lebih banyak mengenai pasaran (Dong et al. 2015).

Analisis kebersandaran melalui kaedah kopula menunjukkan wujudnya struktur kebersandaran yang berbeza bagi jenis data yang berbeza. Kopula Gaussan merupakan kopula terbaik bagi data harian, manakala kopula SJC merupakan kopula terbaik bagi data limaminit. Anggaran parameter yang dihasilkan oleh kopula SJC bagi data lima-minit menunjukkan bahawa kebersandaran pasangan KLCI-FBMHS adalah lebih kuat dalam tempoh pasaran normal berbanding tempoh krisis, dan mengimplikasikan bahawa kepelbagaian portfolio bagi indeks konvensional (KLCI) dan Islam (FBMHS) bukanlah strategi yang berkesan terutamanya dalam tempoh krisis. Kesimpulannya, data lima-minit boleh mencerminkan kemeruapan pasaran saham dengan lebih tepat dan memberikan maklumat yang lebih banyak mengenai pasaran dan kopula dinamik dapat menunjukkan pergerakan parameter kebersandaran yang berubah mengikut masa. 
Skop data kajian ini terhad kepada pasangan indeks KLCI dan FBMHS, dua jenis data iaitu data harian dan data lima-minit, model ARMA-GARCH bagi empat jenis taburan reja terpiawai, dan enam jenis kopula (versi statik dan dinamik). Kajian lanjutan dicadangkan dengan mengambil kira pasaran saham dari negara-negara Asia yang lain sebagai sampel kajian, serta menggunakan beberapa model marginal dan kopula yang pelbagai.

\section{PENGHARGAAN}

Terima kasih diucapkan kepada Universiti Kebangsaan Malaysia (UKM) dan Kementerian Pendidikan Malaysia (KPM) atas bantuan dana yang diberikan bagi menaja penyelidikan ini di bawah geran FRGS (Kod projek: FRGS/1/2019/STG06/UKM/01/5) dan GUP (Kod projek: GUP-2019-031).

\section{RUJUKAN}

Ab Razak, R. \& Ismail, N. 2019. Dependence modeling and portfolio risk estimation using GARCH-copula approach. Sains Malaysiana 48(7): 1547-1555.

Ab Razak, R. \& Ismail, N. 2014. Dependence measures in Malaysian stock market. Malaysian Journal of Mathematical Sciences 8(S): 109-118.

Ab Razak, R., Ismail, N. \& Aridi, N.A. 2016. Is Islamic stock market no different than conventional stock market? An evidence from Malaysia. International Business Management 10(17): 3914-3920.

Aminuddin, N.H., Ab Razak, R. \& Ismail, N. 2018a. Dependence measure of daily versus weekly returns. International Journal of Engineering \& Technology 7(3.20): 329-333.

Aminuddin, N.H., Ab Razak, R. \& Ismail, N. 2018b. Dependence modelling using GARCH, EGARCH, and copula models: A case study on Malaysia stock markets. Asia Proceedings of Social Sciences, The 4th International Conference 2018 (AIC 2018) 2: 55-59.

Aussenegg, W. \& Cech, C. 2008. Simple time-varying copula estimation. http://ssrn.com/abstract=1313714. Diakses pada 14 Disember 2016.

Boubaker, H. \& Sghaier, N. 2016. Markov-switching timevarying copula modeling of dependence structure between oil and GCC stock markets. Open Journal of Statistics 6: 565-589.

Cheong, C.W., Cherng, L.M., Mohamed Isa, N. \& Hoong, P.K. 2017. The HARX-GJR-GARCH skewed-t multipower realized volatility modelling for S\&P 500. Sains Malaysiana 46(1): 107-116.

Chin, W.C., Lee, M.C. \& Yap, G.L.C. 2016. Modelling financial market volatility using asymmetric-skewed-ARFIMAX and HARX Mmodels. Inzinerine Ekonomika-Engineering Economics 27(4): 373-381.

Cubillos-Rocha, J.S., Gomez-Gonzalez, J.E. \& Melo-Velandia, L.F. 2019. Detecting exchange rate contagion using copula functions. North American Journal of Economics and Finance 47: 13-22.

Dong, T., Yang, B. \& Tian, T. 2015. Volatility analysis of Chinese stock market using high-frequency financial big data. https:// ieeexplore.ieee.org/document/7463815. Diakses pada 30 Ogos 2018.
Embrechts, P., McNeil, A. \& Straumann, D. 2002. Correlation and Dependence in Risk Management: Properties and Pitfalls, in Risk Management: Value at Risk and Beyond. Cambridge: Cambridge University Press.

Hammoudeh, S., Mensi, W., Reboredo, J.C. \& Nguyen, D.K. 2014. Dynamic dependence of the global Islamic equity index with global conventional equity market indices and risk factors. Pacific-Basin Finance Journal 30: 189-206.

Hussain, S.I. \& Li, S. 2018. The dependence structure between Chinese and other major stock markets using extreme values and copulas. International Review of Economics and Finance 56: 1-17.

Joe, H. 1997. Multivariate Models and Dependence Concepts. New York: Chapman and Hall.

Kara, E.K. \& Kemaloglu, A. 2016. Portfolio optimization of dynamic copula models for dependent financial data using change point approach. Communications 65(2): 175-188.

Karmakar, M. \& Paul, S. 2018. Intraday portfolio risk management using VaR and CVaR: A CGARCH-EVT-copula approach. International Journal of Forecasting 35(2): 699709.

Liew, R.Q. \& Wu, Y. 2013. Pairs trading: A copula approach. Journal of Derivatives \& Hedge Funds 19(1): 12-30.

McNeil, A.J., Frey, R. \& Embrechts, P. 2005. Quantitative Risk Management: Concepts, Techniques and Tools. New Jersey: Princeton University Press.

Messaoud, S.B. \& Aloui, C. 2015. Measuring risk of portfolio: GARCH-copula model. Journal of Economic Integration 30(1): 172-205

Mokni, K. \& Youssef, M. 2019. Measuring persistence of dependence between crude oil prices and GCC stock markets: A copula approach. The Quarterly Review of Economics and Finance 72: 14-33.

Necula, C. 2010. Modeling the dependency strucuture of stock index returns using a copula function approach. Romanian Journal of Economic Forecasting 13(3): 93-107.

Nelson, R.B. 2006. An Introduction to Copulas. New York: Springer.

Patton, A.J. 2006. Modelling asymmetric exchange rate dependence. International Economic Review 47(2): 527-556.

Reuters, T. 2017. State of the Global Islamic Economy Report 2017/2018. https://www.slideshare.net/ EzzedineGHLAMALLAH/state-of-the-global-islamiceconomy-20172018. Diakses pada 25 Jun 2019.

Salma, J. 2015. Crude oil price uncertainty and stock markets in Gulf corporation countries: A VaR-GARCH copula model. Global Journal of Management and Business Research: C Finance 15(10): 28-38.

Shamiri, A., Hamzah, N.A. \& Pirmoradian, A. 2011. Tail dependence estimate in financial market risk management: Clayton-Gumbel copula approach. Sains Malaysiana 40(8): 927-935.

Thongkamhong, P., Sirisrisakulchai, J. \& Liu, J. 2017. Portfolio optimization under market upturn and market downturn: Empirical evidence from the ASEAN-5. 3rd International Conference on Management Economics and Social Sciences. Organized by Innovative Research Publication. Pattaya, Thailand. 8-9 July.

Ugurlu, E., Thalassinos, E. \& Muratoglu, Y. 2014. Modeling volatility in the stock markets using GARCH models: 
European emerging economies and Turkey. International Journal in Economics and Business Administration II(3): $72-87$.

Xiao, Y. 2020. The risk spillovers from the Chinese stock market to major East Asian stock markets: A MSGARCH-EVTcopula approach. International Review of Economics and Finance 65: 173-186.

Nurul Hanis Aminuddin Jafry* \& Noriszura Ismail Jabatan Sains Matematik

Fakulti Sains dan Teknologi

Universiti Kebangsaan Malaysia

43600 UKM Bangi, Selangor Darul Ehsan

Malaysia
Ruzanna Ab Razak

Economics and Quantitative Methods Unit

Faculty of Management

Multimedia University

63100 Cyberjaya, Selangor Darul Ehsan

Malaysia

*Pengarang untuk surat-menyurat; email: nurulhanis.fst@gmail. com

Diserahkan: 22 Januari 2020

Diterima: 29 April 2020 